\title{
TRANSFORMASI FIQH EMPAT MADZHAB KE DALAM KOMPILASI HUKUM ISLAM TENTANG SAKSI NIKAH
}

\author{
Irma Yullianti \\ Alumni UIN Sunan Gunung Djati Bandung \\ Jalan. A.H Nasution No. 105 Bandung \\ Email: irma.yulianti28@gmail.com
}

\begin{abstract}
Abstrak
Kompilasi Hukum Islam (KHI) merupakan kitab Undang-undang hukum Islam yang dikeluarkan melalui Instruksi Presiden Nomor 1 Tahun 1991 yang bertujuan untuk mengatur umat muslim di Indonesia khususnya di bidang hukum keluarga. Ketentuan-ketentuan di dalamnya didasarkan pada sumber-sumber hukum Islam. Isi kitab kompilasi tersebut dibagi atas tiga buku dengan Hukum Perkawinan sebagai salah satu bahasannya. Dalam perkawinan disyaratkan adanya dua orang saksi, dimana terdapat perbedaan antara keempat imam madzhab. Tulisan ini mengangkat bagaimana perbedaan tersebut disikapi sebelum kemudian dituangkan dalam KHI dan menjadi dasar pengambilan keputusan di peradilan agama.
\end{abstract}

\section{Kata kunci:}

Kompilasi Hukum Islam, Hukum Perkawinan, Saksi Nikah

\section{A. Pendahuluan}

Beberapa konsep fiqh kini banyak yang telah berubah bentuk dan pindah posisi. Ia tidak hanya tertuang di dalam kitab-kitab fiqh klasik, tetapi telah menjadi materi baku dalam peraturan perundangundangan suatu Negara seperti yang terjadi di Indonesia. Perubahan dan perpindahan ini berdampak berubahnya sifat dan watak fiqh itu sendri. Ia tidak lagi ijtihadi, mukhtalafih, dan tidak mengikat, tetapi menjadi ijma'íy dan muttafaq 'alaih (hasil kesepakatan) serta memiliki daya ikat dan daya paksa. Perubahan sifat dan watak ini akibat telah terjadinya proses terjadinya transformasi fiqh ke dalam Undang-undang (qanun) setelah sebelumnya melalui proses legislasi (taqnin). ${ }^{1} \mathrm{Di}$ Indonesia, usaha-usaha transformasi fiqh ke dalam peraturan per-

${ }^{1}$ Atang Abdul Hakim, Fiqih Perbankan Syari'ah (Transformasi Fiqh Muamalah ke dalam Peraturan Perundang-undangan). (Bandung: PT Refika Aditama, 2011), hlm. 8. 
undang-undangan telah dilakukan, seperti yang terlihat dalam Kompilasi Hukum Islam (KHI).

Kompilasi Hukum Islam (KHI) terdiri dari peraturan-peraturan hukum Islam yang sesuai dengan kondisi kebutuhan hukum dan kesadaran hukum umat Islam di Indonesia. Tujuan perumusan Kompilasi Hukum Islam tersebut di Indonesia adalah untuk menyiapkan pedoman yang seragam (unifikasi) bagi hakim Pengadilan Agama dan menjadi hukum positif yang wajib dipatuhi oleh seluruh bangsa Indonesia yang beragama Islam. ${ }^{2}$ Ia bukan merupakan madzhab baru dalam fiqh Islam, melainkan merupakan wujud dan penerapan berbagai madzhab fiqh yang ada untuk menjawab persoalan yang ada di Indonesia sesuai dengan kesadaran hukum masyarakat Islam Indonesia.

KHI merupakan kitab Undang-undang hukum Islam yang dikeluarkan melalui Instruksi Presiden Nomor 1 Tahun 1991 yang bertujuan untuk mengatur khususnya di bidang hukum keluarga. Isi pembahasan dari kitab Undang-undang tersebut dibagi atas tiga buku yaitu, Buku Pertama membahas tentang Hukum Perkawinan, Buku Kedua membahas tentang Hukum Kewarisan dan Buku Ketiga berisi tentang Hukum Perwakafan.

Tahapan yang telah dilalui sampai terbentuknya legislasi atau taqnin dalam penyusunan KHI tersebut menyangkut tiga hal. Pertama yaitu proses persiapan berupa mempersiapkan rancangan Undangundang dalam bentuk perencanaan yang dilaksanakan oleh sebuah tim pelaksana proyek yang ditunjuk dengan SKB (Surat Keputusan Bersana) Ketua Mahkamah Agung dan Menteri Agama RI No. 07/KMA/1985 dan No. 25 Tahun 1985 pada tanggal 25 Maret 1985. Kedua, dalam urusan ini tidak melalui DPR tetapi memakai sistem potong kompas karena kalau melalui DPR akan sulit, apalagi dalam masalah waris. Oleh karenanya Mahkamah Agung menggunakan jalan pintas bersama-sama dengan Departemen Agama mengadakan kompilasi, dan biayanya atas restu Presiden. Ini cara potong kompas, yang zaman dulu tidak mungkin dilakukan, hal ini seperti yang dikemukakan oleh Rahmat Djatnika. ${ }^{3}$ Ketiga, proses pengesahan (berupa Inpres No. 1 Tahun 1991) dan Presiden meminta kepada Menteri Agama untuk menyebarluaskan Kompilasi Hukum Islam yang sudah disepakati tersebut.

${ }^{2}$ Abdurrahman, Kompilasi Hukum Islam di Indonesia. Jakarta : Akademika Pressindo, 1992) hlm. 20.

${ }^{3}$ (Abdurrahman, 2010:50) 
Runtutan dan tahapan transformasi fiqh menjadi Undangundang bermula dari Al-syari'at dalam pengertian Al-Qur'an dan AlSunnah. Al-syari'at merupakan pijakan, landasan, dan rujukan fuqaha dalam memahami, menggali dan menetapkan hukum suatu peristiwa. Produk dari proses pemikiran dan pemahaman fuqaha tersebut terwujud dalam bentuk ilmu fiqh, fatwa, qanun, dan qadha. ${ }^{4}$

Keempat macam produk ini memiliki karakteristik yang berbeda. Ilmu fiqh bersifat umum dan meliputi semua aspek hukum. Ia bersifat ijtihady karena direduksi dari pemikiran dan penalaran mendalam fuqaha. Oleh karena itu, diantara cirinya ialah mukhtalaf fih dan tidak memiliki daya ikat.

Fatwa berarti nasihat, petuah dan respon terhadap peristiwa hukum. Pemberi fatwa (mufti) di dalam merespons peristiwa hukum tidak selalu atas dasar permintaan individu, kelompok, maupun lembaga tetapi bisa juga karena inisiatif mufti itu sendiri. Qanun adalah peraturan perundang-undangan di Negara Islam yang dirumuskan, khususnya, oleh fuqaha dan para ahli lainnya. Di Indonesia peraturan perundang-undangan dirumuskan oleh para penyelenggara Negara yaitu eksekutif dan legislatif. Ia memiliki daya ikat dan daya paksa karena merupakan hasil konsensus bersama. ${ }^{5}$

Qadha merupakan keputusan pengadilan agama. Ia lebih khusus dibandingkan fiqh dan cenderung dinamis, karena hanya meliputi aspek tertentu sesuai dengan perkara yang dihadapi masyarakat. Dari sisi kekuatan hukum, ia lebih mengikat terutama bagi para pihak yang berperkara. Pergeseran dan atau perubahan dari al-syari'at ke fiqh, dari fiqh ke fatwa, dari fiqh ke qanun, dan ke qadha, atau secara berurutan dari al-syari'at ke fiqh ke fatwa ke qanun lalu ke qadha adalah proses transformasi. 6 Nilai-nilai fiqh tersebut selanjutnya mengalami perubahan bentuk (transform) ketika ia menjadi materi Kompilasi Hukum Islam dalam bentuk Inpres No. 1 Tahun 1991.

Produk ijtihad yang tercantum di dalam Kompilasi Hukum Islam sangatlah banyak, misalnya di bidang hukum keluarga salah satunya tentang perkawinan. Seperti di dalam pasal $2 \mathrm{KHI}$ menyebutkan bahwa perkawinan menurut hukum Islam adalah pernikahan, yaitu akad yang

\footnotetext{
${ }^{4}$ Abdul Hakim, Fiqih Perbankan. hlm. 26

${ }^{5}$ Abdul Hakim, Fiqih Perbankan, hlm . 26-27

${ }^{6}$ Abdul Hakim, Fiqih Perbankan, hlm. 27
} 
sangat kuat atau miitsaaqon gholiidhan untuk mentaati perintah Allah SWT dan melaksanakannya merupakan ibadah. Agar berlangsungnya suatu perkawinan yang sah, maka harus terpenuhinya rukun dan syarat perkawinan. Untuk melaksanakan perkawinan harus ada, calon suami, calon istri, wali nikah, dua orang saksi, dan ijab dan Kabul.

Terdapat perbedaan pendapat di kalangan imam madzhab, Imam Syafi'i, Hanafi dan Hambali sepakat bahwa perkawinan itu tidak sah tanpa adanya saksi, tetapi Imam Hanafi memandang cukup dengan hadirnya dua orang laki-laki, atau seorang laki-laki dengan dua orang perempuan, tanpa disyaratkan harus adil. Namun mereka berpendapat bahwa kesaksian kaum wanita saja tanpa laki-laki dinyatakan tidak sah. ${ }^{7}$

Dengan adanya perbedaan pendapat tersebut, maka timbullah masalah di masyarakat bahwa di dalam setiap melangsungkan pernikahan terjadi keberagaman pemahaman dalam perlunya menghadirkan saksi nikah. Mereka masih mengikuti fiqh madzhab yang diyakininya. Dengan adanya permasalahan tersebut, maka perlu adanya aturan yang dapat menyeragamkan hukum terkait masalah tersebut. Tranformasi fiqh ke dalam Kompilasi Hukum Islam merupakan salah satu solusi agar terciptanya keseragaman hukum serta bersifat memaksa. Sehingga dengan demikian tidak akan ada lagi keberagaman dalam penerapan hukum itu sendiri.

Kepastian hukum bagi warga negara merupakan hal yang penting demi terciptanya tertib hukum di setiap Negara. Dengan mempositifkan hukum Islam secara terumus dan sistematik dalam kitab hukum terdapat beberapa sasaran pokok yang hendak dituju. ${ }^{8}$ Adapun tujuan terbentuknya Kompilasi Hukum Islam diantaranya yaitu, melengkapi pilar peradilan agama, menyamakan persepsi peranan hukum Islam, mempercepat proses taqrib bayn al-ummah, dan menyingkirkan paham private affairs. Hal tersebut sesuai dengan kaidah fiqh yang berbunyi:

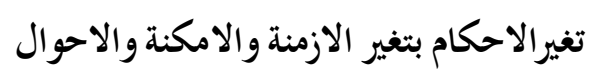

"Perubahan hukum itu berdasarkan perubahan zaman tempat dan keadaan". ${ }^{9}$

\footnotetext{
hlm. 314

${ }^{7}$ Muhammad Jawad Mughniyah, Fiqih Lima Madzhab, (Jakarta: Lentera2011),

${ }^{8}$ Cik Hasan Bisri, Kompilasi Hukum Islam dan Peradilan Agama dalam Sistem Hukum Nasional . (Jakarta : Logos Wacana Ilmu. 1999) hlm. 1

${ }_{9}^{9}$ Muhlish Usman, Kaidah-kaidah Ushuliyah dan Fiqhiyah. (Bogor: PT Raja Grafindo Persada. 1997) hlm.:145
} 
Pada dasarnya, fiqh tidak dapat begitu saja mengatur kehidupan rakyat sebelum ia menjadi Undang-undang (qanun), karena fiqh tidak memiliki daya ikat dan daya paksa seperti yang dimiliki oleh qanun. Oleh karena itu, agar fiqh menjadi hukum positif maka fiqh harus ditransformasikan ke dalam qanun.

\section{B. Pendapat Empat Madzhab Fiqh tentang Saksi Nikah}

Keempat madzhab (Madzhab Hanafi, Madzhab Maliki, Madzhab Syafi'i, dan Madzhab Hambali) telah bersepakat bahwa saksi merupakan syarat sahnya pernikahan. Pernikahan tidak sah tanpa dua saksi selain wali, karena sabna Nabi saw. yang diriwayatkan oleh Aisyah:

$$
\text { لا نكا ح إلا بو لي و شا هدي عد ل. روه الدارقطني وابن حبان }
$$

"Tidaklah ada pernikahan melainkan dengan wali dan dua orang saksi yang adil." (HR. Daruqutni dan Ibnu Hibban).10

Berikut ini penjelasan para imam madzhab yang ditulis dalam sebuah kitab dan dijadikan sebuah rujukan oleh masing-masing madzhab (Madzhab Hanafi, Madzhab Maliki, Madzhab Syafi'i, dan Madzhab Hambali).

\section{Madzhab Hanafi}

Sebagaimana menurut para ulama Hanafiah, persaksian itu syarat rukun akad nikah. Oleh karena itu, persaksian disyaratkan ketika rukun akad.11 Adapun dalam kitabnya Al-Mabsuth, Al-Sarakhsi berkata:

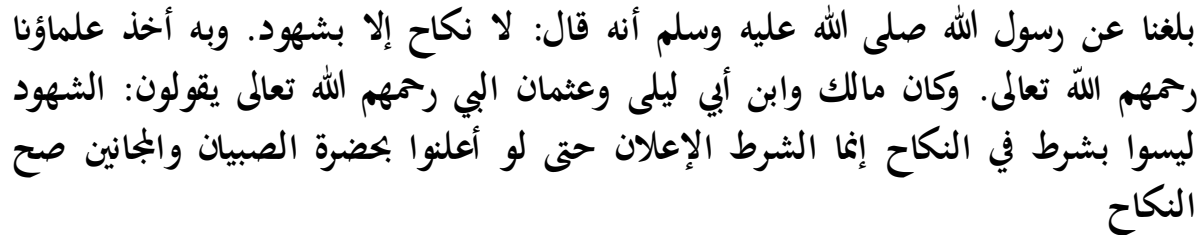

"Telah sampai kepada kami hadits dari Rasulullah Saw. bahwa beliau bersabda, "Pernikahan tidak sah kecuali jika ada saksi." Pendapat ini diambil oleh para ulama kami, semoga Allah merahmati mereka semua. Malik, Ibn Abi Laila dan 'Utsman alBasti menyatakan bahwa saksi bukanlah syarat dalam pernikahkan. Namun syarat pernikahan adalah i'lān (mengumumkan pernikahan). Bahkan sekalipun mereka mengumumkan perni-

${ }^{10}$ Wahbah Az-Zuhaili, Fiqih Islam Wa Adillatuhu (Jakarta: Gema Insani. 2011) hlm. 73

11 Wahbah Az-Zuhaili, Fiqih Islam. hlm. 75 
kahan dihadapan para anak kecil atau para orang gila, pernikahan itu tetap sah.12

Jika mempelai memerintahkan kedua saksi agar tidak mengumumkan akad, maka pernikahannya tidak sah. Hujjah mereka dalam hal demikian adalah sabda Rasulullah Saw.:

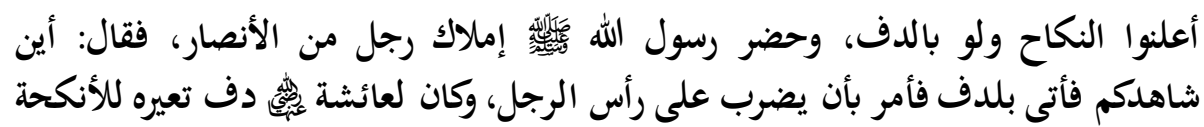

"Umumkanlah pernikahan meski dengan tabuhan rebana." Rasulullah Saw. pernah menghadiri pernikahan seorang lelaki Anshar. Beliau lantas bertanya, "Mana saksi kalian?" Lelaki itu pun datang membawa rebana. Beliau pun memerintahkan agar rebana itu ditabuh dibawah pimpinan si lelaki itu. 'Aisyah ra. pun memiliki rebana yang dia pinjamkan untuk pesta pernikahan ${ }^{13}$.

Dengan demikian, yang haram adalah menyembunyikan pernikahan sedangkan sebaliknya adalah halal. Pengumuman itu dilakukan untuk menghilangkan tuduhan-tuduhan. Hujjah kami dalam hal ini adalah hadits yang telah kami paparkan serta hadits dari Ibn 'Abbas ra. bahwa Rasulullah Saw. bersabda:

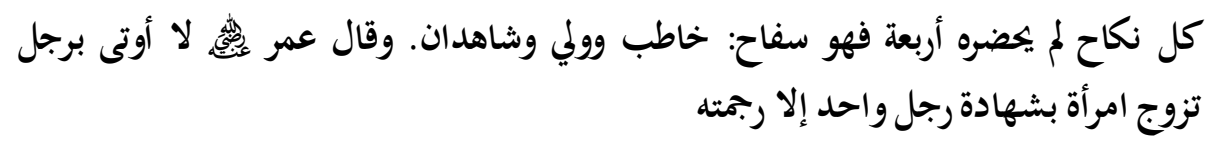

"Setiap pernikahan yang tidak dihadiri oleh empat orang ini adalah zina, yaitu mempelai lelaki, wali dan dua orang saksi." 'Umar ra. berkata, "Tidaklah aku didatangkan seorang lelaki yang menikahi seorang perempuan yang hanya disaksikan oleh seorang lelaki melainkan aku pasti akan merajamnya.".14

Karena yang menjadi syarat adalah mengumumkan, maka yang dianggap adalah pengumuman secara syari'at, yaitu dengan kesaksian dua orang saksi. Sebab, dengan kesaksian keduanya pernikahan itu tidak lagi menjadi rahasia. Seorang penyair berkata:

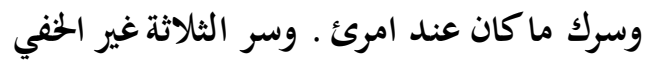

30-31

${ }^{12}$ Syamsuddīn al-Sarakhsi, T.th al-Mabsūth, jilid v. Dār al-Ma'rifah, Beirut. hlm.

13 Ibid, hlm. 31

${ }^{14}$ Syamsuddīn al-Sarakhsi, T.th al-Mabsūth, jilid v. hlm. 31 
"Rahasiamu adalah apa yang ada dalam diri seseorang. Sedang rahasia tiga orang bukanlah rahasia lagi". ${ }^{15}$

Oleh karena itu disaratkannya penambahan seseorang dalam akad ini menunjukkan pentingnya kesaksian dalam pernikahan, dengan demikian penambahan seseorang dalam sebuah pernikahan dimaksud untuk sebuah pernikahan itu bisa dikatakan sah. Hal ini dibedakan dari kasus-kasus serupa yang harus menambahkan dua orang saksi. Namun demikian dalam hal pernikahan dibedakan dari kasus-kasus serupa dengan menambahkan dua orang saksi.

Menurut golongan Hanafiah, pada dasarnya setiap orang yang dapat melaksanakan akad, pernikahan pun sah dengan kesaksiannya (wali dan kedua mempelai). Setiap orang yang dapat menjadi wali dalam pernikahan, maka dapat pula menjadi saksi dalam pernikahan itu. ${ }^{16}$ Menurut aliran madzhab ini bahwa pernikahan tetap sah dengan kesaksian dua orang yang fasik. Namun Imam al-Syafi'i memandang bahwa pernikahan tidak sah dengan kesaksian dua orang fasik berdasarkan sabda Rasulullah Saw.,

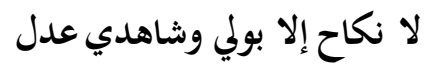

"Pernikahan tidak sah kecuali dengan adanya seorang wali dan dua orang saksi yang adil”.

Sebenarnya, hal ini didasarkan pada kenyataan bahwa orang fasik menurut madzhab Hanafi termasuk orang yang dapat memberikan kesaksian. Kesaksiannya tidak dapat diterima ketika dia dituduh berdusta. Sedangkan ketika dia menghadiri dan mendengarkan kesaksian, tuduhan ini tidak mungkin terjadi. Sehingga pada saat itu dia dianggap orang yang adil. Adapun Imam Syafi'i berpendapat bahwa orang fasik sama sekali tidak termasuk orang yang dapat memberikan kesaksian karena dalam dirinya ada kekurangan, yaitu kefasikan. Menurut golongan Hanafiah, hal ini juga didasarkan pada kenyataan bahwa kefasikan tidak akan mengurangi keimanan. Sedangkan keimanan tidaklah bertambah dan tidak pula berkurang. Selain itu, perbuatanperbuatan berasal dari ajaran-ajaran keimanan (beragama Islam), bukan dari keimanan itu sendiri. 
Menurut golongan Hanafiah, kefasikan tidak menghalangi seseorang untuk menjadi imam atau penguasa. Sebab, para imam setelah Khulafaur Rasyidin sedikit sekali yang terhindar dari sifat fasik. Sebab pendapat yang menyatakan bahwa seseorang tidak berhak menjadi imam karena kefasikan akan berdampak pada kerusakan besar. Jika dia berhak menjadi imam, artinya dia berhak memberikan keputusan (menjadi qadhi). Sebab, jabatan qadhi dipegang juga oleh imam. Jika dia berhak menjadi qadhi, artinya dia berhak memberikan kesaksian. Dengan demikian, tampak jelaslah perbedaan antara kefasikan dan kekurangan dalam keimanan (bukan yang tergolong orang-orang baik).

Aliran madzhab Hanafi berpendapat bahwa, seseorang yang buta kesaksiannya tidak dapat diterima. Sebab, dia tidak mampu membedakan orang yang harus dia berikan kesaksiannya kecuali dengan petunjuk yang samar, yaitu nada dan suara. Sementara hal tersebut tidak terjadi pada saat dia hadir dan mendengar karena nada dan suara yang diucapkan terkesan formal. ${ }^{17}$ Sedangkan Imam Syafi'i berbeda pendapat:

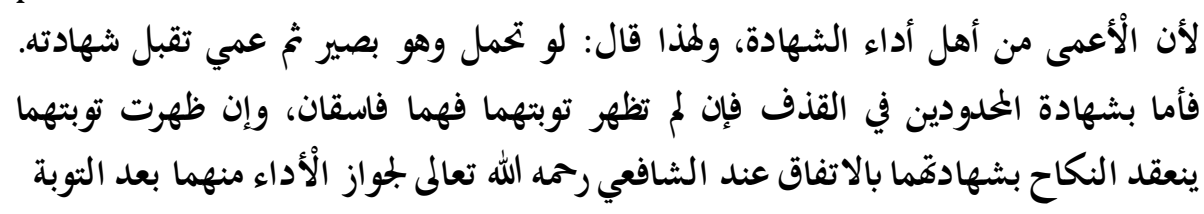

"Orang buta termasuk orang yang boleh memberikan kesaksian. Karena itu dia berkata bahwa jika orang itu dapat melihat saat menjadi saksi, lantas menjadi buta, maka kesaksiannya dapat diterima. Sedangkan kesaksian dua orang yang dikenakan hudud karena qadzaf (menuduh orang lain berzina), jika keduanya tidak terlihat bertaubat maka keduanya adalah orang fasik. Namun jika keduanya tampak bertaubat, maka pernikahan sah dengan kesaksian keduanya. Sebab, kesaksian seperti kedua orang itu dapat diterima jika keduanya bertaubat." 18

Madzhab Hanafi juga memandang bahwa kesaksian orang yang terkena hudud karena qadzaf tidak dapat diterima. Sebab, dia dihukum sebagai pendusta. Hal itu akan mempengaruhi terhadap tuduhannya sebagai pendusta atau terhadap klaim keduanya. Dan itu tidak terjadi saat keduanya hadir dan mendengarkan. Adapun kesaksian dua orang budak dan dua orang anak kecil, maka pernikahan tidak sah. Sebab,

${ }^{17}$ Ibid, hlm. 32

${ }^{18}$ Syamsuddīn al-Sarakhsi, T.th al-Mabsūth, jilid v. hlm. 32 
keduanya tidak terhitung dalam akad ini dan karena mereka tidak berhak terlibat dalam wilayah akad. Ini karena pernikahan dilangsungkan dalam majelis orang-orang dewasa. Sedangkan para anak kecil dan budak biasanya tidak diundang dalam majelis orang-orang dewasa. Dengan demikian kehadiran mereka sama dengan ketidakhadirannya. ${ }^{19}$

Berikut ini hadits perbedaan pendapat antara Hanafi dan Syafi'i;

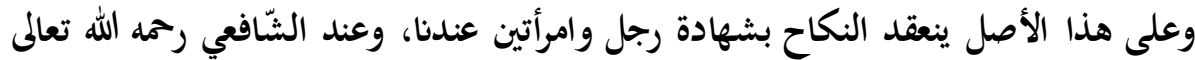

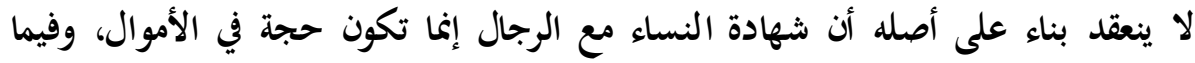

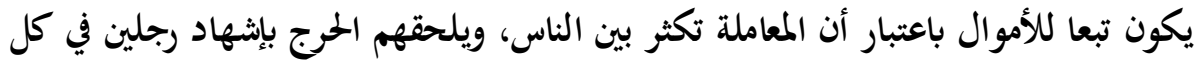

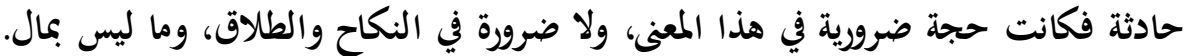

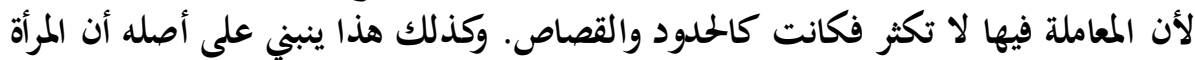
لا تصلح أن تكون موجبة للنكاح ولا قابلة

"Pernikahan sah dengan kesaksian seorang lelaki dan dua orang wanita. Sedangkan menurut al-Syafi'i ra., pernikahannya tidak sah. Sebab, pada dasarnya kesaksian para wanita disertai para lelaki hanya menjadi hujjah dalam bidang harta atau bidang lain yang berkaitan dengan harta dengan alasan bidang mu'amalah sering terjadi di tengah masyarakat. Dan akan terjadi kesulitan jika dalam setiap kejadian yang boleh bersaksi hanya dua orang lelaki. Dengan demikian, kesaksian mereka mau tidak mau dapat menjadi hujjah dalam hal ini. Namun itu tidak dapat dijadikan hujjah dalam bidang pernikahan, talak dan bidang selain harta. Sebab, mu'amalah dalam hal ini tidak banyak. Sehingga hal ini sama seperti hudud dan qishash. Selain itu, atas dasar ini, wanita tidak dapat menjadi orang yang melakukan ijab-qabul dalam pernikahan, juga tidak dapat menjadi saksi dalam pernikahan". ${ }^{20}$

Adapun hadits yang menjelaskan kebolehan wanita menjadi saksi dalam madzhab Hanafi:

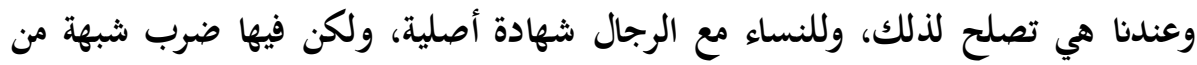

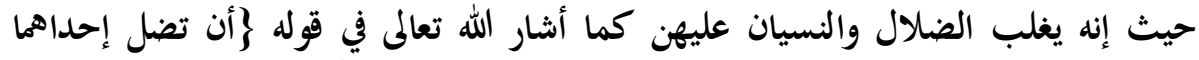

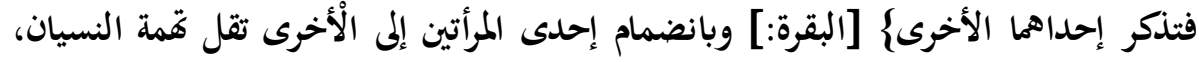

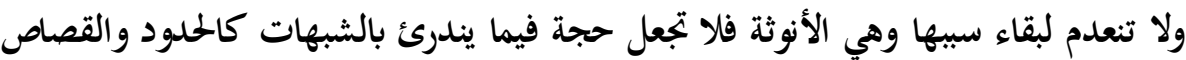

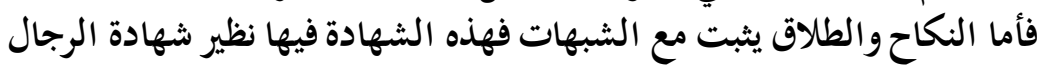
"Wanita dapat menjadi saksi. Para wanita yang disertai para lelaki memiliki hak kesaksian. Namun dalam hal ini mengandung

${ }^{19}$ Syamsuddīn al-Sarakhsi, T.th al-Mabsūth, jilid v. hlm. 32

${ }^{20}$ Syamsuddīn al-Sarakhsi, T.th al-Mabsūth, jilid v. hlm. 32 
semacam kesamaran karena wanita biasanya melenceng dan lupa sebagaimana yang Allah Swt. isyaratkan dalam firman-Nya, "Agar jika salah satunya lupa, maka yang lainnya dapat mengingatkannya." Dengan bergabungnya seorang wanita kepada seorang wanita lainnya, tuduhan lupa akan diminimalisir. Meski tuduhan ini tidak mungkin dapat dihilangkan karena statusnya sebagai wanita sehingga dia tidak dapat dijadikan hujjah dalam sesuatu yang di dalamnya tidak boleh ada kesamaran, seperti dalam hudud dan qishash. Adapun pernikahan dan talak, tetap berlaku meski ada kesamaran. Maka kesaksian wanita ini sebanding dengan kesaksian lelaki. ${ }^{21}$

Tidak diragukan bahwa tuduhan melenceng dan lupa dalam bersaksi saat hadir tidak terjadi. Karena itu hendaknya pernikahan dapat dilangsungkan dengan kesaksian seorang lelaki dan seorang wanita. Namun menurut madzhab ini bahwa telah menjadi ketetapan berdasarkan nash bahwa dua wanita dianggap satu saksi. Artinya, seorang wanita dianggap setengah saksi. Dan dengan setengah saksi, sesuatu tidak dapat berlaku. Karena itulah, jika dua orang lelaki dan seorang wanita bersaksi lantas mereka mundur dari kesaksian, maka wanita itu tidak dianggap apapun.

\section{Madzhab Maliki}

Para ulama Malikiah berpandangan bahwa persaksian merupakan syarat sah nikah, baik itu ketika melangsungkan akad dan sebelum berhubungan suami-istri. Dianjurkan persaksian tersebut ada ketika akad nikah. Jika persaksian ketika akad atau sebelum terjadi hubungan suami-istri tidak sah, akad nikah tersebut dianggap rusak. Bersenggamanya dengan istri pun dihitung bermaksiat $d$ an pernikahan tersebut harus dibatalkan. ${ }^{22}$

Menurut aliran Malikiah, persaksian merupakan syarat dibolehkannya bersenggama dengan si istri, bukan syarat sahnya akad. Inilah titik perbedaan ulama Malikiah dan ulama lainnya. ${ }^{23}$ Dalam kitab AlMuwattha dijelaskan bahwa:

\footnotetext{
${ }^{21}$ Syamsuddīn al-Sarakhsi, T.th al-Mabsūth, jilid v. hlm. 33

22 Wahbah Az-Zuhaili, Fiqih Islam Wa Adillatuhu (Jakarta : Gema Insani.2011) hlm. 75

${ }^{23}$ Wahbah Az-Zuhaili, Fiqih Islam hlm. 75
} 


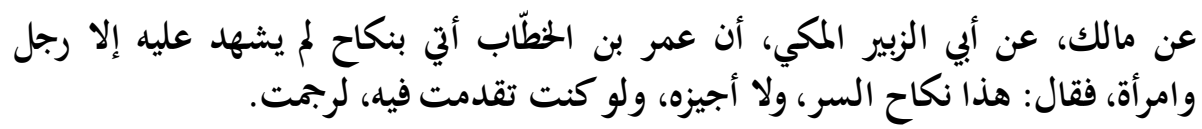

"Atsar dari Malik, dari Abu al-Zubair al-Makki. Abu al-Zubair berkata bahwa diberitahukan kepada 'Umar bahwa ada pernikahan yang tidak disaksikan kecuali oleh seorang lelaki dan perempuan. 'Umar pun berkata, "Ini adalah nikah sirri. Aku tidak memperbolehkannya. Kalaulah aku menghadirinya, aku pasti akan merajamnya" .24

Pernikahan sirri menurut Imam Malik merupakan sebuah pernikahan yang si suami berpesan kepada para saksi agar menyembunyikan pernikahan tersebut dari istrinya atau dari khalayak umum sekalipun itu keluarga sendiri. Sebagai penguat disyaratkannya saksi dalam sebuah pernikahan, para ulama Malikiah berkata, "Nikah sir ri itu rusak dengan talak ba'in jika suami istri tersebut telah melakukan persenggamaan. Sebagaimana juga rusaknya pernikahan tanpa saksi dengan terjadi hubungan suami istri. Mereka berdua dikenakan had zina; jilid atau rajam, jika telah terjadi persenggamaan dan hal itu mereka akui. Atau persengamaan tersebut terbukti dengan persaksian empat saksi, seperti dalam kasus perzinaan. Mereka berdua tidak diberi ampunan hanya karena ketidaktahuan mereka. ${ }^{25}$

Akan tetapi mereka berdua tidak dikenakan had, jika pernikahan mereka telah menyebar dan diketahui oleh banyak orang, seperti dengan diiringi pemukulan rebana, diadakan walimah, disaksikan satu orang selain wali, atau disaksikan dua saksi fasik dan sejenisnya. Nabi saw. pernah bersabda:

$$
\text { ادروا الحدود با لشبهات. }
$$

"Halangilah had itu dengan hal-hal syubhat" (Hadits dari Ibnu Abbas yang diriwayatkan oleh Ibnu Adi). ${ }^{26}$

\section{Madzhab Syafi'i}

Muslim ibn Khalid dan Sa'id telah mengabarkan kepadaku (alSyafi'i), dari Juraij, dari 'Abdullah ibn 'Utsman ibn Khaitsam, dari Sa'id ibn Jubair dan Mujahid, dari Ibn 'Abbas. Ibn 'Abbas berkata, hlm. 194

${ }^{24}$ Mālik ibn Anas, al-Muwaththa'. Jam'iyyah al-Maknaz al-Islāmi. Kairo : 1421 H,

25 Wahbah Az-Zuhaili, 2011:74

${ }^{26}$ Wahbah Az-Zuhaili, Fiqih Islam, hlm. 74 


$$
\text { لا نكاح إلا بشاهدي عدل، وولي مرشد ـ وأحسب مسلم بن خالد قد سمعه من ابن خيثم }
$$

"Pernikahan tidak sah kecuali dengan adanya dua saksi yang adil dan seorang wali yang memimpin." Aku menduga bahwa Muslim ibn Khalid telah mendengarnya dari Ibn Khaitsam. ${ }^{27}$

Al-Syafi'i berkata:

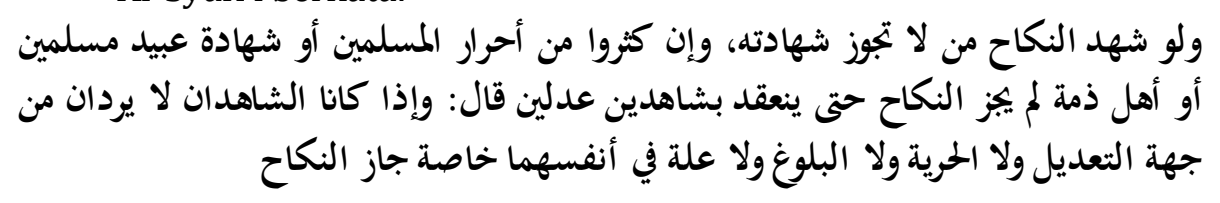

“Jika pernikahan dipersaksikan oleh orang yang kesaksiannya tidak diperbolehkan, sekalipun mereka banyak, baik mereka adalah orang-orang muslim yang merdeka, para budak muslim maupun orang-orang kafir dzimmi, maka pernikahan tersebut tidak sah. Kecuali jika dilangsungkan dengan kesaksian dua orang saksi yang adil. Al-Syafi'i berkata lagi: jika kedua orang saksi itu tidak ditolak dari segi keadilan, kemerdekaan, kebaligan juga tidak ada aib di dalam diri keduanya, pernikahan diperbolehkan/ sah".

Al-Syafi'i juga berkata, jika kedua saksi itu adil namun musuh bagi mempelai wanita atau mempelai lelaki namun kedua mempelai itu sepakat untuk melakukan pernikahan, maka kesaksian kedua saksi itu sah karena itu adalah kesaksian dua orang yang adil. Namun jika kedua mempelai mengingkarinya, maka kesaksian mereka berdua tidak sah. Sebab, aku tidak memperbolehkan kesaksian keduanya untuk kedua musuhnya. Lalu aku meminta salah satu orang yang mengingkari itu untuk bersumpah. Jika dia telah bersumpah, dia terlepas dari kewajiban. Namun jika dia menolak untuk bersumpah, maka aku mengembalikan sumpah itu kepada orang yang mengatakannya. Jika dia bersumpah, aku menetapkan pernikahannya. Namun jika dia tidak mau bersumpah, aku tidak menetapkan pernikahannya. ${ }^{28}$

Jika diketahui ada seorang lelaki memasuki tempat seorang wanita, lantas wanita itu mengatakan, "Suamiku," sedang lelaki itu mengatakan, "Ini istriku, aku menikahinya dengan dua orang saksi yang

${ }^{27}$ Muḥammad ibn Idrīs al-Syāfi' i, al-Umm. Bait al-Afkār al-Dauliyyah, Riyadh hlm.

${ }^{28}$ Ibid. hlm. 885 
adil," maka pernikahannya sah. Jika kita tidak tahu kedua saksi itu, alSyafi'i berkata:

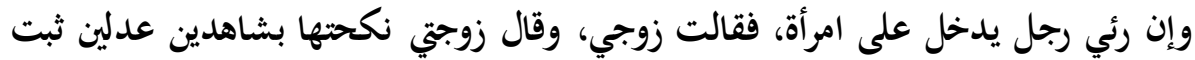

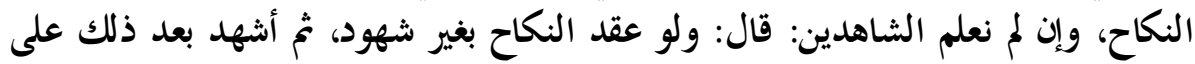

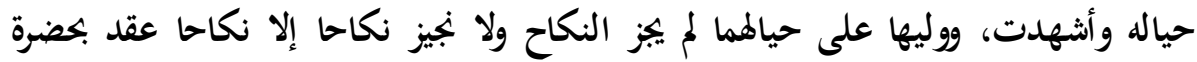

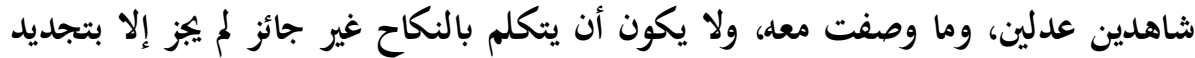

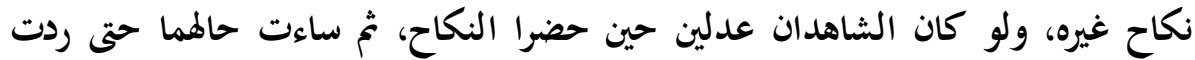

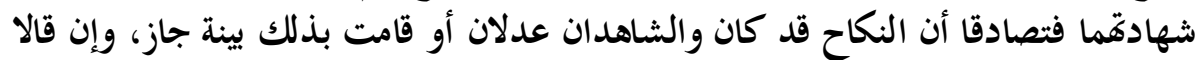
كان النكاح وهما بحالمما لم يجز أنجاح.

"Jika pernikahan dilangsungkan tanpa saksi, lalu mempelai pria, mempelai wanita dan walinya mempersaksikan status pernikahan itu, pernikahan itu tidak sah. Kami pun tidak memperbolehkan pernikahan kecuali jika pernikahan itu dilangsungkan dihadapan dua orang saksi yang adil. Pernikahan seperti itu tidak boleh, kecuali jika pernikahannya diulang. Jika kedua saksi itu adil pada saat menghadiri pernikahan, namun sikapnya menjadi buruk setelah itu sampai-sampai kesaksiannya ditolak tetapi kedua mempelai menyatakan bahwa pernikahan itu telah dilangsungkan dan kedua saksi itu adil serta diperkuat oleh bukti, maka pernikahan itu tetap sah. Namun jika kedua mempelai itu menyatakan bahwa pada saat pernikahan berlangsung kedua saksi itu sikapnya seperti sekarang (buruk), maka pernikahan itu tidak sah." 29

Kemudian Al-Syafi'iberkata:

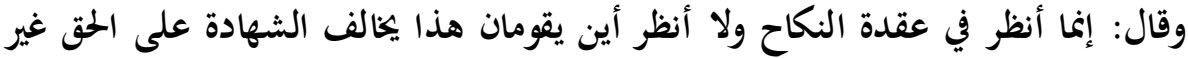

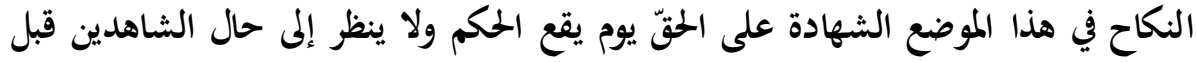

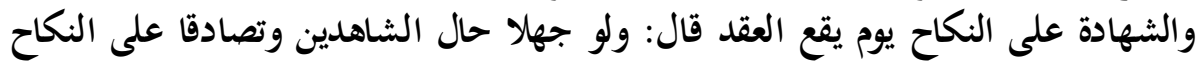

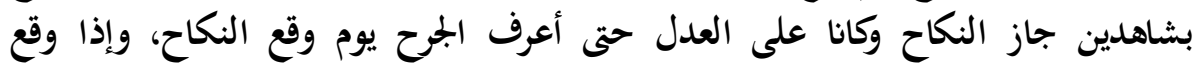

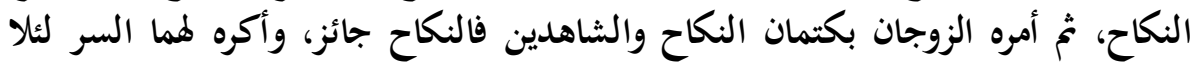
يرتاب بمما

"Aku hanya mempertimbangkan akad nikah. Aku tidak mempertimbangkan dimana kedua mempelai berada. Kesaksian atas kebenaran dipertimbangkan pada hari terjadinya pernikahan. Sebelum itu, kondisi kedua saksi tidak dipertimbangkan. Kesaksian atas pernikahan dipertimbangkan pada hari dilang-

${ }^{29}$ Muhammad ibn Idrīs al-Syāfi'i, al-Umm.hlm. 885 
sungkannya akad." Dia juga berkata, "Jika kedua mempelai tidak tahu kondisi kedua saksi namun keduanya menyatakan telah menikah dengan dua saksi, maka pernikahannya sah. Kedua saksi itu dianggap adil sampai ada hal menyatakan sebaliknya dihari berlangsungnya pernikahan. Jika pernikahan telah dilangsungkan, lalu kedua mempelai menyuruh orang-orang untuk menyembunyikan pernikahan dan kondisi kedua saksi, pernikahan itu tetap sah. Namun aku tidak suka keduanya karena telah menyembunyikan hal itu. Sebab hal tersebut akan mengundang tuduhan." 30

Dengan demikian menurut Imam Syafi'i kondisi saksi itu dipertimbangkan ketika terjadinya akad nikah. Jika kedua mempelai tidak mengetahui kondisi saksi pada saat akad nikah, maka pernikahan nya dianggap sah sampai ada hal yang menyatakan sebaliknya.

\section{Madzhab Hambali}

Ibn Qudāmah sebagaimana menjelaskan dalam kitabnya bahwa:

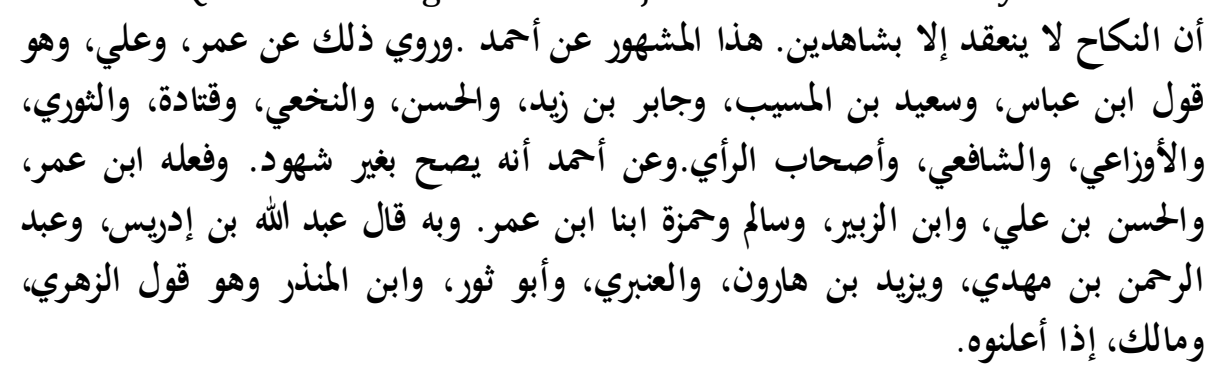

"Pernikahan tidak sah kecuali dengan adanya dua saksi. Inilah pendapat yang terkenal dari Imam Ahmad Hal ini diriwayatkan pula dari 'Umar dan 'Ali. Ini juga adalah pendapat Ibn 'Abbas, Sa'id ibn al-Musayyib, Jabir ibn Zaid, al-Hasan, al-Nakha'i, Qatadah, alTsauri, al-Auza'i, al-Syafi'i dan para ahli ra'yu. Diriwayatkan pula dari Imam Ahmad bahwa pernikahan itu tetap sah meski tanpa ada saksi. Hal ini dilakukan oleh Ibn 'Umar, al-Hasan ibn 'Ali, Ibn al-Zubair, Salim dan Hamzah putra Ibn 'Umar. Hal ini dikatakan pula oleh 'Abdullah ibn Idris, 'Abdurrahman ibn Mahdi, Yazid ibn Harun, al-'Anbari, Abu Tsaur, Ibn al-Mundzir. Inilah pendapat alZuhri dan Malik, jika mereka mengumumkan pernikahan (tanpa ada saksi)". ${ }^{31}$

\footnotetext{
${ }^{30}$ Muhammad ibn Idrīs al-Syāfíi i, al-Umm. hlm. 885-886

${ }^{31}$ Ibn Qudāmah al-Maqdisi, al-Mughni. Bait al-Afkār al-Dauliyyah, Riyadh : 2004: hlm. 1584
} 
Ibn al-Mundzir berkata:

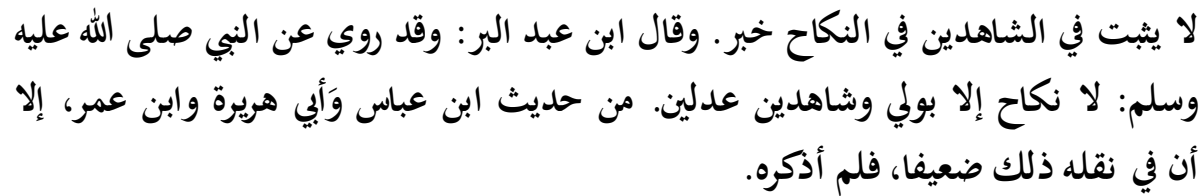

"Tak ada hadits yang shahih tentang dua saksi dalam pernikahan." Ibn 'Abdul Barr berkata, "Telah diriwayatkan dari Nabi Saw., 'Pernikahan tidak sah kecuali dengan adanya seorang wali dan dua orang saksi yang adil.' Hadits ini berasal dari Ibn 'Abbas, Abu Hurairah dan Ibn 'Umar. Namun hadits ini dhaif pada sanadnya. Karena itu aku tidak menyebutkannya".

Selanjutnya Ibn al-Mundzir berkata:

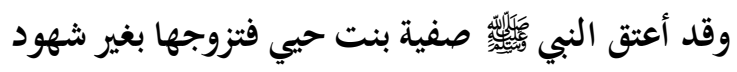

"Nabi Saw. telah membebaskan Shafiyyah binti Huyay. Lalu beliau menikahinya tanpa ada saksi". ${ }^{32}$

Anas ibn Malik ra. berkata, "Rasulullah Saw. membeli seorang budak perempuan dengan harga tujuh qirsy. Lalu orang-orang pun berkata, 'Kita tidak tahu apakah Rasulullah Saw. akan menikahinya atau menjadikannya sebagai ummu walad. Ketika beliau hendak naik kendaraan, beliau menutupnya dengan hijab.' Dari sana mereka pun tahu bahwa beliau menikahi budak perempuan itu.". Ibn al-Mundzir berkata, "Orang-orang mengindikasikan terjadinya pernikahan itu dari hijab yang dibentangkan." Yazid ibn Harun berkata, "Allah Ta'ala memerintahkan agar diadakan saksi dalam jual-beli, namun tidak demikian dalam pernikahan. Lalu para ahli ra'yu mensyaratkan adanya persaksian dalam pernikahan. Namun mereka tidak mensyaratkan hal itu dalam jual-beli. Alasan untuk pendapat pertama adalah hadits yang diriwayatkan dari Nabi Saw. bahwa beliau bersabda, "Pernikahan tidak sah kecuali dengan adanya seorang wali yang memimpin dan dua orang saksi yang adil." Hadits ini diriwayatkan oleh al-Khallal melalui sanadnya.

Akan tetapi dalam hadits yang diriwayatkan oleh Al-Daruquthni dari Aisyah bahwa Nabi Saw. bersabda:

$$
\text { لا بد في النكاح من أربعة. الولي، والزوج ، والشاهدان }
$$

32 Ibn Qudāmah al-Maqdisi, 2004: 1584 
"Dalam pernikahan harus ada empat unsur yaitu: wali, mempelai pria, dan dua orang saksi".

Karena pernikahan tidak hanya berkaitan dengan dua orang yang melakukan akad, tapi berkaitan pula dengan anak, disyaratkanlah adanya persaksian. Ini dilakukan agar si ayah kelak tidak mengingkari anak itu, agar nasabnya tidak hilang. Hal ini berbeda dengan jual-beli. Adapun pernikahan Nabi Saw. yang tidak ada wali dan tanpa adanya saksi, ini adalah termasuk kekhususan bagi beliau dalam pernikahan. Sehingga orang lain tidak boleh melakukannya. ${ }^{33}$

Pernikahan tidak sah kecuali dengan kesaksian dua orang muslim, baik apakah kedua mempelai adalah muslim maupun hanya suami saja yang muslim. Hal ini dikatakan oleh Imam Ahmad. Ini juga adalah pendapat al-Syafi'i. Abu Hanifah berkata, "Jika mempelai wanita adalah seorang dzimmi, pernikahannya sah dengan kesaksian dua pria dzimmi." Abu al-Khaththab berkata, "Hal ini juga yang kami pilih, didasarkan pada riwayat yang mengatakan bahwa kesaksian para dzimmi terhadap dzimmi lainnya dapat diterima. Menurut kami, sabda Nabi Saw., 'Pernikahan tidak sah kecuali dengan adanya seorang wali dan dua orang saksi yang adil.' menunjukkan pernikahan bagi orang muslim. Sehingga pernikahan ini tidak sah dilakukan dengan kesaksian dua orang dzimmi. Seperti halnya pernikahan orang-orang muslim." 34

\section{Saksi Nikah dalam Kompilasi Hukum Islam}

Paparan fuqaha mengenai saksi nikah di atas memberikan inspirasi kepada para perumus Kompilasi Hukum Islam untuk menjadikannya sebagai salah satu materi Undang-undang. Penjelasan mengenai saksi nikah tersebut dijadikan teknik operasional di Pengadilan Agama yang termaktub dalam penjelasan Kompilasi Hukum Islam Bab IV Bagian Keempat tentang saksi nikah pasal 24, 25,dan 26 berbunyi:

\section{Pasal 24}

(1) Saksi dalam perkawinan merupakan rukun pelaksanaan akad nikah.

(2) Setiap perkawinan harus disaksikan oleh dua orang saksi.

33 Ibn Qudāmah al-Maqdisi, al-Mughni. hlm. 1584

${ }^{34}$ Ibid. hlm. 1584 
Pasal 25

"Yang dapat ditunjuk menjadi saksi dalam akad nikah ialah seorang lakilaki muslim, adil, aqil, baligh, tidak terganggu ingatan, dan tidak tuna rungu atau tuli."

Pasal 26

"Saksi harus hadir dan menyaksikan secara langsung akad nikah serta mendatangani akta nikah pada waktu dan di tempat akad nikah dilangsungkan."

Dapat ditarik kesimpulan bahwa syarat saksi dalam pernikahan yang dijelaskan dalam Kompilasi Hukum Islam yaitu, saksi sebagai rukun pelaksanaan akad nikah, dua orang laki-laki muslim, adil, akil baigh, tidak terganggu ingatan, tidak tuna rungu atau tuli, menyaksikan langsung akad nikah, dan menandatangani akta nikah pada waktu dan tempat akad nikah dilangsungkan.

Para aliran madzhab berbeda pendapat, menurut Madzhab Hanafi persaksian itu merupakan syarat rukun akad nikah. Oleh karena itu persaksian disyaratkan ketika rukun akad nikah. Madzhab ini mensyaratkan kesaksian dua orang saksi. Akan tetapi menurut golongan Hanafiah pun pernikahan sah dengan kesaksian seorang laki-laki dan dua orang peremuan. Hal ni sesuai dengan hadits:

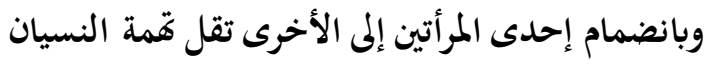

"Dengan bergabungnya seorang wanita kepada seorang wanita lainnya, tuduhan lupa akan diminimalisir."

Menurut aliran madzhab ini bahwa pernikahan tetap sah dengan kesaksian dua orang yang fasik. Sebenarnya, hal ini didasarkan pada kenyataan bahwa orang fasik menurut madzhab Hanafi termasuk orang yang dapat memberikan kesaksian. Kesaksiannya tidak dapat diterima ketika dia dituduh berdusta. ${ }^{35}$. Abu Hanifah berkata:

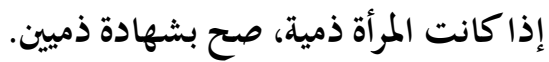

"Jika mempelai wanita adalah seorang dzimmi, pernikahannya sah dengan kesaksian dua pria dzimmi” ${ }^{36}$

${ }^{35}$ Syamsuddīn al-Sarakhsi. T.th al-Mabsūth, jilid v. Dār al-Ma'rifah, Beirut. hlm.

${ }^{36}$ Ibn Qudāmah al-Maqdisi, al-Mughni. hlm. 1584 
Aliran madzhab Hanafi berpendapat bahwa, seseorang yang buta kesaksiannya tidak dapat diterima. Sebab, dia tidak mampu membedakan orang yang harus dia berikan kesaksiannya kecuali dengan petunjuk yang samar, yaitu nada dan suara. Adapun kesaksian dua orang budak dan dua orang anak kecil, maka pernikahan tidak sah. Sebab, keduanya tidak terhitung dalam akad ini dan karena mereka tidak berhak terlibat dalam wilayah akad. Ini karena pernikahan dilangsungkan dalam majelis orang-orang dewasa.

Madzhab Maliki berpandangan bahwa persaksian merupakan syarat sah nikah, baik itu ketika melangsungkan akad dan sebelum berhubungan suami-istri. Menurut aliran Malikiah, persaksian merupakan syarat dibolehkannya bersenggama dengan si istri, bukan syarat sahnya akad. Menurut para ulama Malikiah Nikah sirri itu rusak dengan talak ba'in jika suami istri tersebut telah melakukan persenggamaan. Akan tetapi mereka berdua tidak dikenakan had, jika pernikahan mereka telah menyebar dan diketahui oleh banyak orang, seperti dengan diiringi pemukulan rebana, diadakan walimah, disaksikan satu orang selain wali, atau disaksikan dua saksi fasik dan sejenisnya.

Menurut madzhab Syafi'i saksi merupakan syarat sahnya akad pernikahan. Dengan kata lain madzhab ini berpendapat bahwa seorang saksi harus menghadiri akad nikah dilangsungkan. Imam Syafi'i berkata:

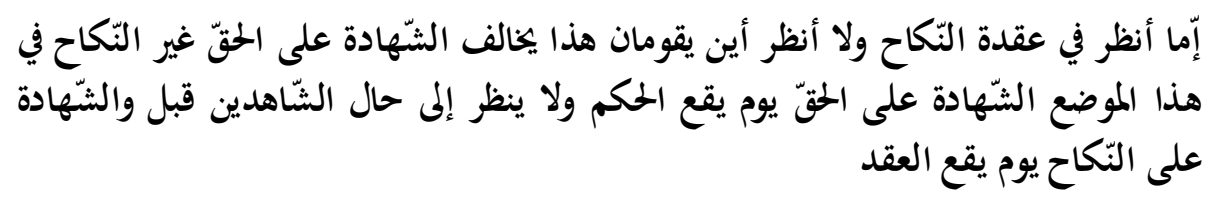

"Aku hanya mempertimbangkan akad nikah. Aku tidak mempertimbangkan dimana kedua mempelai berada. Kesaksian atas kebenaran dipertimbangkan pada hari terjadinya pernikahan. Sebelum itu, kondisi kedua saksi tidak dipertimbangkan. Kesaksian atas pernikahan dipertimbangkan pada hari dilangsungkannya akad". ${ }^{37}$

Pernikahan juga dikatakan sah dengan adanya dua orang saksi yang adil, merdeka, baligh dan tidak fasik. Saksi harus hadir ketika akad dilangsungkan dan pernikahan tidak sah kecuali dengan kesaksian dua orang muslim, baik apakah kedua mempelai adalah muslim maupun

${ }^{37}$ Muḥammad ibn Idrīs al-Syāfi' i, al-Umm. Bait al-Afkār al-Dauliyyah, Riyadh hlm. 
hanya suami saja yang muslim. Imam al-Syafi'i memandang bahwa pernikahan tidak sah dengan kesaksian dua orang fasik berdasarkan sabda Rasulullah Saw.,

$$
\text { لا نكاح إلا بولي وشاهدي عدل }
$$

"Pernikahan tidak sah kecuali dengan adanya seorang wali dan dua orang saksi yang adil"

Kesaksian orang buta dapat diterima, menurut Imam Syafi'i beliau berpendapat:

$$
\text { لأن الأعمى من أهل أداء الثهادة، ولهذا قال: لو تحمل وهو بصير ثم عمي تقبل شهادته. }
$$

"Orang buta termasuk orang yang boleh memberikan kesaksian.

Karena itu dia berkata bahwa jika orang itu dapat melihat saat menjadi saksi, lantas menjadi buta, maka kesaksiannya dapat diterima". 38

Para pengikut madzhab Syafi'i memiliki dua pend apat dalam hal ini, ada yang mengatakan tidak sah dan ada yang mengatakan kesaksian ini diterima. Artinya orang buta kesaksiannya sah. Kesaksiannya dapat diterima jika kedua orang buta itu meyakini suara kedua mempelai dan mengenali suara keduanya tanpa ada keraguan sedikit pun seperti halnya orang yang dapat melihat mengenalinya. 39

Menurut Imam Syafi'i, pernikahan tidak sah dengan kesaksian seorang lelaki dan dua orang perempuan. Hal ini sesuai dengan hadits dari al-Zuhri:

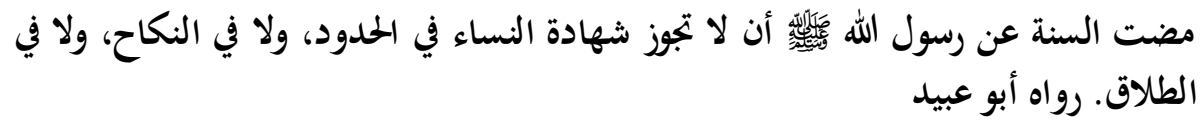

"Kebiasaan yang telah terjadi dimasa Rasulullah Saw. adalah kesaksian wanita tidak diterima dalam hal hudud, pernikahan maupun dalam talak." Ini diriwayatkan oleh Abu 'Ubaid”.

Menurut Imam Hambali, beliau bersabda:

$$
\text { أن النكاح لا ينعقد إلا بشاهدين. }
$$

"Pernikahan tidak sah kecuali dengan adanya dua saksi".

Diriwayatkan pula dari Imam Ahmad bahwa :

"Pernikahan itu tetap sah meski tanpa ada saksi".

$$
\text { وعن أحمد أنه يصح بغير شهود. }
$$

${ }^{38}$ Syamsuddīn al-Sarakhsi, T.th al-Mabsūth, jilid v. Dār al-Ma'rifah, Beirut. hlm.32

${ }^{39} \mathrm{Ibn}$ Qudāmah al-Maqdisi, 2004: 1585 
Ibn al-Mundzir berkata:

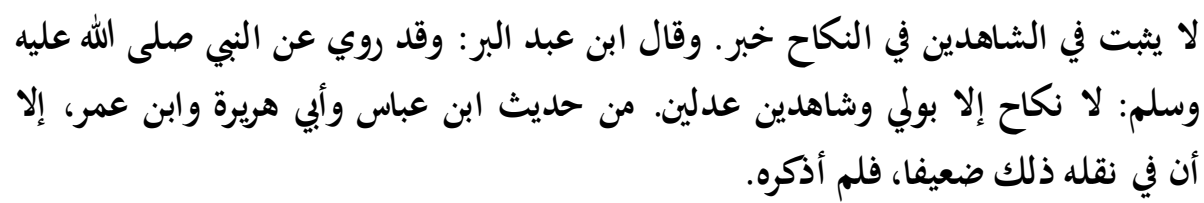

"Tak ada hadits yang shahih tentang dua saksi dalam pernikahan." Ibn "Abdul Barr berkata, "Telah diriwayatkan dari Nabi Saw., 'Pernikahan tidak sah kecuali dengan adanya seorang wali dan dua orang saksi yang adil.' Hadits ini berasal dari Ibn 'Abbas, Abu Hurairah dan Ibn 'Umar. Namun hadits ini dhaif pada sanadnya. Karena itu aku tidak menyebutkannya".

Selanjutnya Ibn al-Mundzir berkata:

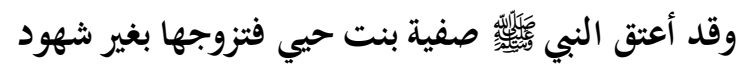

"Nabi Saw. telah membebaskan Shafiyyah binti Huyay. Lalu beliau menikahinya tanpa ada saksi”.

Dengan demikian menurut Imam Hambali bahwa adanya saksi bukanlah rukun dalam akad nikah, karena beliau memiliki dua pendapat. Menurut Imam Hambali pernikahan tidak sah kecuali dengan kesaksian dua orang muslim, baik apakah kedua mempelai adalah muslim maupun hanya suami saja yang muslim. Karena pernikahan tidak hanya berkaitan dengan dua orang yang melakukan akad, tapi berkaitan pula dengan anak, disyaratkanlah adanya persaksian. Ini dilakukan agar si ayah kelak tidak mengingkari anak itu, agar nasabnya tidak hilang. 40

Pernikahan tidak sah dengan kesaksian dua orang anak kecil. Sebab, mereka berdua tidak termasuk orang yang dapat memberikan kesaksian. Namun dimungkinkan pernikahan sah dengan kesaksian dua orang remaja yang telah balig. Pernikahan tidak sah dengan kesaksian dua orang gila atau orang-orang yang tidak dapat memberikan kesaksian. Sebab keberadaannya sama dengan ketidakadaannya. Pernikahan juga tidak sah dengan kesaksian dua orang tuli, sebab mereka tidak mendengar. Tidak sah pula dengan kesaksian dua orang bisu, sebab keduanya tidak dapat memberikan kesaksian jika diminta. ${ }^{41}$

40 Ibn Qudāmah al-Maqdisi, 2004:1584

${ }^{41}$ Ibn Qudāmah al-Maqdisi, 2004: 1585 
Tabel 1.1

Matriks Transformasi Madzhab Fiqh Terhadap KHI Tentang Saksi Nikah

\begin{tabular}{|l|c|c|c|c|}
\hline KHI (Pasal 24, 25, 26) & $\begin{array}{c}\text { Madzhab } \\
\text { Hanafi }\end{array}$ & $\begin{array}{c}\text { Madzhab } \\
\text { Maliki }\end{array}$ & $\begin{array}{c}\text { Madzhab } \\
\text { Syafi'i }\end{array}$ & $\begin{array}{c}\text { Madzhab } \\
\text { Hambali }\end{array}$ \\
\hline $\begin{array}{l}\text { Rukun pelaksanaan } \\
\text { akad nikah }\end{array}$ & $\sqrt{ }$ & - & $\sqrt{ }$ & - \\
\hline Dua orang & - & - & $\sqrt{ }$ & $\sqrt{ }$ \\
\hline Laki-laki muslim & - & - & $\sqrt{ }$ & $\sqrt{ }$ \\
\hline Adil & - & - & $\sqrt{ }$ & $\sqrt{ }$ \\
\hline Akil baligh & $\sqrt{ }$ & - & $\sqrt{ }$ & $\sqrt{ }$ \\
\hline $\begin{array}{l}\text { Tidak terganggu } \\
\text { ingatan }\end{array}$ & $\sqrt{ }$ & - & $\sqrt{ }$ & $\sqrt{ }$ \\
\hline Tidak tunarungu/tuli & $\sqrt{ }$ & - & $\sqrt{ }$ & $\sqrt{ }$ \\
\hline $\begin{array}{l}\text { Menyaksikan langsung } \\
\text { akad nikah }\end{array}$ & $\sqrt{ }$ & $\sqrt{ }$ & $\sqrt{ }$ & - \\
\hline $\begin{array}{l}\text { Menandatangani akta } \\
\text { nikah pada waktu dan } \\
\text { tempat akad nikah } \\
\text { dilangsungkan }\end{array}$ & - & - & - & - \\
\hline
\end{tabular}

Berdasarkan tabel di atas, dapat disimpulkan bahwa pada dasarnya keempat madzhab fiqh (madzhab Hanafi, madzhab Maliki, madzhab Syafi'i, dan madzhab Hambali) memberikan kontribusi terhadap ketentuan Kompilasi Hukum Islam dalam Bab IV Bagian Ke empat pasal 24, 25, dan 26 tentang saksi nikah dengan cara mentransformasikan dari fiqh menjadi Undang-undang melalui proses legislasi (taqnin) yang dilakukan oleh berbagai pihak. Akan tetapi bentuk kontribusi yang diberikan oleh keempat madzhab itu berbeda-beda. Madzhab Hanafi berpendapat bahwa dari sembilan poin yang telah dirinci dalam Kompilasi Hukum Islam hanya menyebutkan lima poin saja yaitu saksi dalam perkawinan merupakan rukun pelaksanaan akad nikah, akil baligh, tidak terganggu ingatan, tidak tuna rungu/ tuli dan menyaksikan langsung akad nikah.

Berbeda dengan madzhab Hanafi, madzhab Maliki hanya menyebutkan satu poin saja dari sembilan poin yang telah dirinci dalam Kompilasi Hukum Islam, yaitu saksi dalam perkawinan merupakan rukun pelaksanaan akad nikah. Begitupun madzhab Syafi'i, dari sembilan poin yang telah disebutkan dalam KHI, menyebutkan ada 
delapan poin ketentuan tentang saksi nikah yaitu, saksi dalam perkawinan merupakan rukun pelaksanaan akad nikah, berjumlah dua orang, laki-laki muslim, adil, akil baligh, tidak terganggu ingatan, tidak tuna rungu/tuli dan menyaksikan langsung akad nikah. Sedangkan madzhab Hambali, hanya menyebutkan enam dari Sembilan poin yang telah dijelaskan dalam KHI yaitu, saksi berjumlah dua orang, laki-laki muslim, adil, akil baligh, tidak terganggu ingatan, dan tidak tuna rungu/ tuli.

Dengan demikian dapat disimpulkan bahwa materi muatan tentang saksi nikah yang telah di transformasikan lebih mengacu pada pendapat madzhab Syafi'i, seperti yang telah digambarkan digambarkan dalam tabel diatas. Hanya satu poin saja yang tidak ada dalam pendapat madzhab Syafi'i yaitu Menandatangani akta nikah pada waktu dan tempat akad nikah dilangsungkan.

Hal ini juga dipengaruhi karena latar belakang masuknya Islam ke Indonesia yang dipengaruhi madzhab Syafi'i. Sejak awal masuknya Islam ke Indonesia madzhab Syafi'i sudah dominan dikalangan masyarakat. Kitab-kitab fiqh karya ulama-ulama madzhab tersebut sudah cukup popular dikalangan umat Islam dan diajarkan dilembaga pendidikan tradisional muslim Indonesia (pesantren) ${ }^{42}$. Madzhab Syafi'i berusaha mengkompromikan pemikiran rasional (al-ra'y) dan literal (al-hadits) terhadap sumber-sumber ajaran Islam. Sehingga pemikirannya tersebut mudah dipahami oleh masyarakat Indonesia.

\section{Penutup}

Pada dasarnya tidak ada satu madzhab pun (madzhab Hanafi, madzhab Maliki, madzhab Syafi'i dan madzhab Hambali) yang menjelaskan bahwa saksi harus menandatangani akta nikah pada waktu dan tempat akad nikah dilangsungkan. Ketentuan pasal 26 yang menyebutkan "serta mendatangani akta nikah pada waktu dan di tempat akad nikah dilangsungkan" perlu untuk dibahas lebih dalam menurut tinjauan fiqih. Karena ulama madzhab terdahulu belum menentukan bahwa saksi harus menandatangani akta nikah pada waktu dan di tempat akad nikah dilangsungkan. Hal ini dikarenakan kondisi terdahulu dan sekarang sudah jauh berbeda. Sehingga hukumpun disesuaikan dengan kebutuhan saat ini.

${ }^{4}$ Muhammad Iqbal, Hukum Islam Indonesia Modern (Dinamika Pemikiran dari Fiqh Klasik ke Fiqh Indonesia) (Tangerang: Gaya Media Pratam.2009) hlm. 57 
Dengan demikian saksi nikah ini sangat penting sekali dalam sebuah pernikahan karena selain termasuk pada salah satu rukun nikah juga mejadi syarat sahnya pernikahan. Bahkan mengenai sah atau tidaknya sebuah pernikahan ditentukan dengan ada tidaknya saksi.

Dari hasil pengkajian terhadap madzhab-madzhab tersebut di atas, untuk umat Islam Indonesia, hukum Islam yang berlaku merupakan hukum yang berasal dari ramuan situasi dan kondisi yang berkembang di dalam masyarakat dan adaptasi dari madzhab-madzhab fiqh yang pernah berkembang dalam sejarah, yang masih relevan dengan lingkungan sosial, budaya dan masyarakat Islam Indonesia. Oleh Hasbi, salah satu tokoh pemikiran tersebut, dinamakan nya dengan fiqh atau hukum Islam "madzhab Indonesia". Pandangan ini sejalan dengan semangat modernitas yang berpegang pada prinsip al-muhafazhah 'ala al-qadim al-shahih wa al-akhdz bi al-jadid al-ashlah (memelihara nilainilai lama yang masih baik (relevan) dengan mengambil nilai-nilai baru yang lebih baik lagi). Pengembangan hukum Islam dengan metode ijtihad tidak harus dimulai dari nol dan membuang pendapat-pendapat lama. Pendapat dan metodologi madzhab yang pernah berkembang dalam sejarah boleh saja diterima dan dipakai, selagi masih bisa dipertanggungjawabkan dan sesuai dengan konteks masa dan tempat sekarang. ${ }^{43}$

\section{DAFTAR PUSTAKA}

Abdurrahman, 1992. Kompilasi Hukum Islam di Indonesia. Akademika Pressindo, Jakarta.

Abdul Qodri A.Azizy, 2001. Transformasi Fiqh dalam Hukum Nasiona, membedah Peradilan Agama. PPHIM Jawa Tengah, Semarang.

Ahmad Rofiq, 1998. Hukum Islam di Indonesia. PT Rajagrafindo Persada, Jakarta.

Amir Syarifudin, 2009. Ushul Fiqh I. Perpustakan Nasional, Jakarta.

Atang Abdul Hakim, 2011. Fiqih Perbankan Syari'ah (Transformasi Fiqh Muamalah ke dalam Peraturan Perundang-undangan). PT Refika Aditama, Bandung.

A. Dzajuli, 2009. Fiqh Siyasah. Kencana, Jakarta.

43 Muhammad Iqbal, Hukum Islam, hlm. 191 
Cik Hasan Bisri dkk, 1999 Kompilasi Hukum Islam dan Peradilan Agama dalam Sistem Hukum Nasional. Logos Wacana Ilmu, Jakarta.

Dedi Supriyadi,2008 Perbandingan Mazhab dengan Pendekatan Baru. CV Pustaka Setia, Bandung.

Ibn Qudamah al-Maqdisi, 2004. al-Mughni. Bait al-Afkār al-Dauliyyah, Riyadh.

Kompilasi Hukum Islam

Malik Ibn Anas, 1421 H al-Muwaththa'. Jam'iyyah al-Maknaz al-Islāmi, Kairo.

Maria Farida Indrati S., 2014. Ilmu Perundang-undangan. Kanisius, Yogyakarta.

Moenawir Chalil, 1990 Biografi Empat Serangkai Imam Madzhab (Hanafi, Maliki, Syafi'i, Hambali). PT Bulan Bintang, Jakarta.

Moh. Nazir, 1988 Metode Penelitian. Ghalia Indonesia, Bogor.

Muhammad Ibn Idrīs al-Syāfi i, T.th al-Umm. Bait al-Afkār al-Dauliyyah, Riyadh.

Muhammad Iqbal, 2009. Hukum Islam Indonesia Modern (Dinamika Pemikiran dari Fiqh Klasik ke Fiqh Indonesia). Gaya Media Pratam, Tangerang.

Muhammad Jawad Mughniyah, 2011 Fiqh Lima Madzhab. Penerbit Lentera, Jakarta.

Muhlish Usman,1997. Kaidah-kaidah Ushuliyah dan Fiqhiyah. PT RajaGrafindo Persada, Jakarta.

Wahbah Az-Zuhaili, 2011. Fiqih Islam Wa Adillatuhu. Gema Insani, Jakarta. 